\title{
Networks and space gain in Japanese budget
}

Tokyo. Despite one of the most austere budgets on record, Japan's science-related ministries have managed to win significant new funding in a number of areas - including computer networks, space technology and university research grants - in the 1994 budget adopted by the cabinet last week.

The overall context is tight. Falling tax revenues, resulting from the prolonged recession, have forced the Ministry of Finance to trim back total government expenditure to $¥ 73,000$ billion (US $\$ 690$ billion), only 1 per cent higher than last year.

The Ministry of International Trade and

\section{Is Japan throwing good money after bad science?}

Tokyo. Despite the general squeeze on budgets (see above), the Japanese government apparently feels that it can afford to boost the budgets of two programmes of questionable scientific value, one into earthquake prediction and the other into cold fusion.

The first of these has come under severe criticism in recent years for its inability to predict earthquakes. External reviewers have raised fundamental objections to the programme, including questioning whether earthquake prediction is scientifically possible (see Nature 364, 370; 1993).

But the programme, now entering is seventh five-year phase, seems destined to carry on much as before, and with even more money. This year it will receive a 30 per cent boost to $¥ 10.6$ billion (US $\$ 100$ million) for the six participating ministries and agencies.

Kiyoo Mogi, head of the coordinating committee for earthquake prediction, described earthquake prediction as a "100-year programme" and said "we should not give up even if we don't have immediate results".

Another anomaly is the Ministry of International Trade and Industry's (MITI's) plan to spend $¥ 540$ million ( $\$ 5.1$ million) on cold fusion research, more than twice the budget for 1993. The programme, euphemistically called research into "new hydrogen energy", will be carried out at a new laboratory recently established in Japan's northern island of Hokkaido.

The laboratory has 6 or 7 researchers drawn from Japanese companies, including Hitachi, Toshiba and Mitsubishi Heavy Industries, and MITI hopes to increase this number to 9 or 10 in fiscal year 1994, which starts on 1 April. The laboratory, which has been operating for only a few months, has yet to produce any evidence of cold fusion.

Japan's increased investment in earthquake prediction and cold fusion illustrates the lack of any effective system for reviewing government research projects.

D. $\mathbf{S}$.
Industry (MITI) has been particularly badly hit. Its budget request for science and technology was cut by $¥ 20$ billion to $¥ 281.9$ billion, only 0.4 per cent up on 1993 . Reduced energy consumption because of the recession has led to a drop in revenue from taxes on electricity, and this in turn has forced MITI to accept a reduction in the funding it receives from this source.

The Science and Technology Agency (STA) fared better, with a 4.1 per cent increase. This is partly because the agency participates in large international programmes, such as the US space station and the International Thermonuclear Experimental Reactor (ITER), that cannot easily be cut back.

STA officials are pleased to have won their full request for $¥ 1.1$ billion for a new interministry computer network linking national research institutes and universities, as well as providing a high-capacity link to overseas. This demonstrates the importance the government now attaches to developing Japan's networks, which lag far behind those of the United States.

This money comes on top of a further sum of between $¥ 7$ and $¥ 8$ billion to be spent on new local area networks (LANS) at Japan's national universities, announced by the government two weeks ago as part of the third 1993 supplementary budget. As a result of this and earlier supplementary budgets, all of Japan's 98 national universities will have campus LANS in the near future, whereas only half a dozen major universities had them a year ago.

The STA's spending on space will continue to grow. Expenditure will include $¥ 4.8$ billion for the development of the unnmanned space shuttle HOPE, an 18-metre vehicle expected to be launched around the end of the decade with Japan's H-II rocket, which was successfully launched for the first time earlier this month.

The budget for Japan's contribution to the US space station will grow to $¥ 46.8$ billion, and a further $¥ 18.3$ billion will be spent on the Advanced Earth Observing Satellite (ADEOS), which will carry sensors from the United States and Europe.

The Ministry of Education, Science and Culture (MESC) continues to inject large amounts of extra money into competitive grants for university research. With $¥ 82.4$ billion in $1994-12$ per cent up on last year - the ministry remains well on target for achieving the goal set in 1992 of nearly doubling the budget to $¥ 100$ billion in a few years. But this budget still remains

small compared with other advanced nations.

MESC has also succeeded in getting an appropriation of $¥ 2$ billion for a B-meson factory to be built at the National Laboratory of High Energy Physics (KEK) in Tsukuba. KEK researchers hope this will eventually become an international project involving high-energy physicists from around the world.

Japan's spending on the International Human Frontier Science Program, which supports international research on the brain and biological functions through a foundation in Strasbourg, France, has been cut by nearly 9 per cent to $¥ 3.6$ billion — the first cut since the foundation was set up in 1989.

MITI officials point out, however, that although the budget has decreased when measured in yen, if the present high exchange value of the yen is maintained, the 1994 budget will rise by nearly 9 per cent over 1993 in dollars to $\$ 34$ million.

The prospects for future expansion of the programme's budget will depend on increased contributions from other participant nations. Last year, European countries, Canada and the United States contributed about $\$ 8$ million, and MITI officials are confident that, with the help of the new director-general of the programme, Michel Cuenod, the European Union will at least increase its contribution in 1994.

David Swinbanks

Highlights of Japan's research budget for 1994 Billion $¥$ $\%$ change

MITI Industrial technology for global environment (RITE) Real World Computing (RWC) 5 th generation computer Intelligent Manufacturing System (IMS) Project Regional technology development DNA analysis New hydrogen energy (cold fusion) Total R\&D budget

STA

Space

Nuclear energy/safety

SPring 8

Special promotion funds

Human Frontier Science Programme Interministry computer network

Total R\&D budget Inciudes 1.5 billion $¥$ from MIT

\section{MESC}

Grants in aid of research

Computer networks

Accelerator physics

(TRISTAN and B Factory)

Astronomy (Hawaii telescope)
82.4

12.0

5.0

1.4

$1.3+12.5$

$1.6+135.9$

$0.4+38.1$

$0.5+145.5$

281.9

$+0.4$

$\begin{array}{rr}156.2 & +7.9 \\ 234.0 & +1.7 \\ 10.6 & +17.8 \\ 15.5 & +16.5 \\ 3.6 & -8.9 \\ 1.1 & - \\ 05.2 & +4.1 \\ & \\ & \\ 82.4 & +12.0 \\ 29.6 & +10.9 \\ 11.8 & -9.2 \\ 4.8 & +20.0\end{array}$

